\title{
SSynthesis
}

International Scientific Conference of IT and Business-Related Research

\section{THE ENTREPRENEURIAL FACETS OF PUBLIC ADMINISTRATION}

\section{PREDUZETNIČKI ASPEKTI JAVNE UPRAVE}

\author{
Konstantinos M. Karyotakis, Maria Bakatsaki, Vassilis S. Moustakis \\ Management Systems Laboratory (ManLab), School of Production Engineering and Management, Technical University of Crete, Chania 73100, Greece
}

\begin{abstract}
:
This paper provides a map of entrepreneurial facets that are considered relevant in the public sector. Mapping aims to highlight entrepreneurial characteristics and behaviour, which are conducive to increasing the effectiveness, efficiency and legitimacy of public administration, with the aim to raise public welfare. Empirical data and literature review show that new behavioural pattern and entrepreneurial practice can provide high-quality services to the public, making simultaneously more rational management of available resources and increasing the overall prosperity of citizens. The paper highlights the concepts of corporate entrepreneurship, innovation and organizational learning in public administration. The conclusions reached in this work indicate that the change and innovation in entrepreneurship are mandatory for survival and development of the public sector.
\end{abstract}

\section{Key words:}

entrepreneurship, public sector, change management.

\section{INTRODUCTION}

The twenty-first century is often characterized as a century of research and technology. In this century, intense, revolutionary and vital changes are observed, both in the internal (material and intangible resources, management systems, processes, activities, etc.) and external environment of an organization (micro environment and macro environment).

The public sector is often considered synonymous with bureaucracy. Rapid global socio-political and technological development has triggered transformation and onset of its entrepreneurial facets in order to improve its effectiveness, efficiency and legitimacy, and live up to the ever increasing expectations and demands of citizens. With the new behavioral patterns and entrepreneurial practices, higher quality services are provided to the public, making simultaneously more rational management of available resources and increasing the overall prosperity of citizens.

However, due to the specificity and role of the public sector, entrepreneurship should be approached with due respect to differences regarding culture and innovations. Along with democracy, such differences should be taken into account when seeking entrepreneurial behavior within public organizations. Additionally, the public administration is characterized by high levels of risk aversion and resistance to change, limited sources,

\section{Apstrakt:}

Ovaj rad nudi prikaz preduzetničkih aspekata koji se smatraju relevantnim u javnom sketoru. Mapiranje ima za cilj da istakne preduzetnička obeležja i obrasce ponašanja, koji su pogodni za povećanje efektivnosti, efikasnosti i legitiminosti javne uprave, a sve to u cilju unapređenja opšteg blagostanja u društvu. Empirijski podaci i pregled literature ukazuju na činjenicu da je kroz nov obrazac ponašanja i preduzetničku praksu, moguće pružiti kvalitetnije usluge javnosti, a istovremeno racionalnije upravljati raspoloživim resursima i povećati sveukupni prosperitet građana. Ovaj rad stavlja poseban naglasak na koncepte korporativnog preduzetništva, inovacije i organizaciono učenje u javnoj upravi. Na osnovu pruženih informacija može se zaključiti da su promene i inovacije u preduzetništvu neophodne za opstanak i razvoj javnog sektora.

\section{Ključne reči:}

preduzetništvo, javni sektor, upravljanje promenama.

lack of direction, vision and management measurement, political disputes and legal restrictions (Alves, 2013).

Continuous technological advances, coupled with the need to improve (if not to optimize) fiscal policies, have imposed significant challenges to public organizations. Governments around the world have established various strategies to reduce public expenditures and encourage growth in order to be able to efficiently cope with the new socioeconomic reality (Osborne et al., 2014). Over the last 15 years, significant efforts have been made, thus forming a more efficient, effective and flexible public sector (Zampetakis \& Moustakis, 2010).

Wilson (2000) supports the attitude that organizational sociologists define most public organizations as large rigid bureaucratic structures that resist change. On the other hand, Baldridge and Burnham (1975) conclude that public sector organizations, primarily due to their size, complexity and heterogeneity, are more likely to innovate. This occurs owing to large problems in coordination, control, administration and management, which arise mainly because of the size of the organizations requiring innovative and entrepreneurial solutions compared to the small, simple and homogeneous organizations.

The present article accentuates on the literature review of public entrepreneurship and attempts to highlight the need for adoption of entrepreneurial behaviour and attitudes with the aim to make the society more sustainable. 


\section{ENTREPRENEURSHIP IN THE PUBLIC SECTOR}

The concept of entrepreneurship in the public sector exists since the 1960s (e.g. Ostrom, 1965; Wagner, 1966). However, some researchers argue that public sector is conservative, bureaucratic and characterized by slow motion rate. Accordingly, any change occurs due to external factors as a result of innovative activities in the private sector or in non-governmental organizations (Rubalcaba-Bermejo, 2007).

Entrepreneurship, as a concept, is a process, which may happen to organizations of any size or type (Kearney et al., 2008). According to Currie et al. (2008), entrepreneurship in the public sector is viewed as a patchwork of three different parts: a) stakeholders, b) entrepreneurship and c) policy. It identifies market opportunities under the existing political conditions, optimizes public sector performance, encourages innovation, and urges the parties to take risk and manage resources properly.

It is shifted from individual to organizational level and from private to social sector, as well as to non-profit sectors. Large traditional organizations have been proposed to adopt entrepreneurial behaviour in order to improve their performance (Zampetakis \& Moustakis, 2010).

Entrepreneurial behavior is multidimensional and cannot be accurately attributed to a single definition. The four main characteristics of a person with strong elements of entrepreneurship include: a) understanding of the needs and receptivity to any changes; b) effective management of the existing knowledge and new ideas in order to be able to properly respond to future needs; c) cultivating intuition; and d) rational use of necessary methods and means for achieving the desired objectives.

Pearce et al. (1997) approach the entrepreneurial behaviour in the public sector through: a) the ability to avoid bureaucracy; b) strategic vision; c) creation of an energetic environment; and d) orientation change. Zampetakis and Moustakis (2010) conclude that through these aspects of entrepreneurial behaviour, added value is created in an organization.

Morris and Jones (1999) present three different approaches for the entrepreneur in the public sector: a) they consider an entrepreneur an individual who deals with the introduction of innovations, trying to increase the efficiency of services and provide better citizen's service; b) they highlight that entrepreneurship is the product of management, leadership principles and strategies in public organizations; and, c) they contend that entrepreneurs in the public sector are employees who can apply innovative solutions to meet the needs and respond properly to the problems of the citizens.

Audretsch (2003) claims that entrepreneurship is the driving force for economic and social development worldwide. Empirical data have unveiled that entrepreneurial practices and behaviour in the public sector induce mostly non- profit benefits (Benz, 2009), thus increasing social welfare more than personal or economic objectives (Zampetakis \& Moustakis, 2007).

Public organizations have the potential to create new value for the society (Kearney et al., 2008). This new value may be positive or negative. That's why it is very important for the public sector to espouse entrepreneurial behavior for positive results. According to Newman (2002), public sector organizations should take into account models and good practices applied in the private sector and adopt entrepreneurial values and behavior, and thus create added value for the society.

Entrepreneurship tends to improve the quality of life of the entire society by means of proper management of the existing resources and conditions, as well as implementation of preven- tive measures, attitudes and behaviour to address possible future problems, needs (social and economic) and innovations. It is a continuous process whose results should be evaluated in the long-term.

Adopting entrepreneurial and innovative attitudes and behaviour, both in the private and public sector, certainly produces lots of benefits, increases the overall efficiency of the corresponding sector. Some of these include the following: the improved service and customer satisfaction, more appropriate reward systems and incentives, better internal procedures, improved communication and better human resource management relations (Kearney et al., 2008).

Zampetakis and Moustakis (2010) approach entrepreneurship in the public sector as a process, which takes place when individuals of an organization act in a way of creating added value to the provided services and increasing social welfare. Entrepreneurship in the public sector will enable them to review previous practices and policies in order to confront new challenges and opportunities.

Covin and Slevin (1991) describe entrepreneurship as a dimension of organization strategy which is interpreted by dynamic behaviour, risk taking, tendency for aggressive competition and dependence of an organization on the frequent and extensive use of innovative products. Based on the aboveprovided description, it can be understood that an organization, as a whole, can behave entrepreneurially (Omar \& Ishak, 2013).

According to Deakins and Freel (2012), the probability of entrepreneurial appearance is a result of both individual or psychological and external or environmental conditions, which betide in an economy. The preferences and skills of individuals, as well as psychological and economic influences they have experienced, affect their behavior (entrepreneurial or not). Furthermore, behavior and attitudes of individuals are affected by the institutional and cultural environment, which encourages (or not) entrepreneurial effort and individual's initiative.

\subsection{CORPORATE ENTREPRENEURSHIP}

Corporate entrepreneurship is a process during which individuals within an organization pursue opportunities regardless of the resources they control (Stevenson \& Jarilo, 2007), applying practices and behavior different from the norm (Vesper, 1990). It can occur either in a pro-existing organization or by creating a new one (Hisrich, 2013). The corporate entrepreneurship objective is to develop and apply new ideas in an organization, thus achieving and change (Zampetakis \& Moustakis, 2007).

Kearney et al. (2008) espoused the point of view that corporate entrepreneurship of a public organization is a hotchpotch of both features within the organization and external factors. Figure 1 shows individual factors from which stems the corporate entrepreneurship, whereas Table 1 provides a summary of these factors.

It should be observed that innovation represents a key dimension of entrepreneurship, which is crucial for the prosperity and flourishing of organizations both in the private and public sector (Bessant, 2005). Change and innovation in the public sector may include (Osborne \& Brown, 2005): a) development of new public organization structures; b) development of new public services; c) development of new management, professional skills and/ or procedures; d) development of new administrative systems and skills; e) development of new ways and methods for civil services; and f) development of new forms of management performance. 


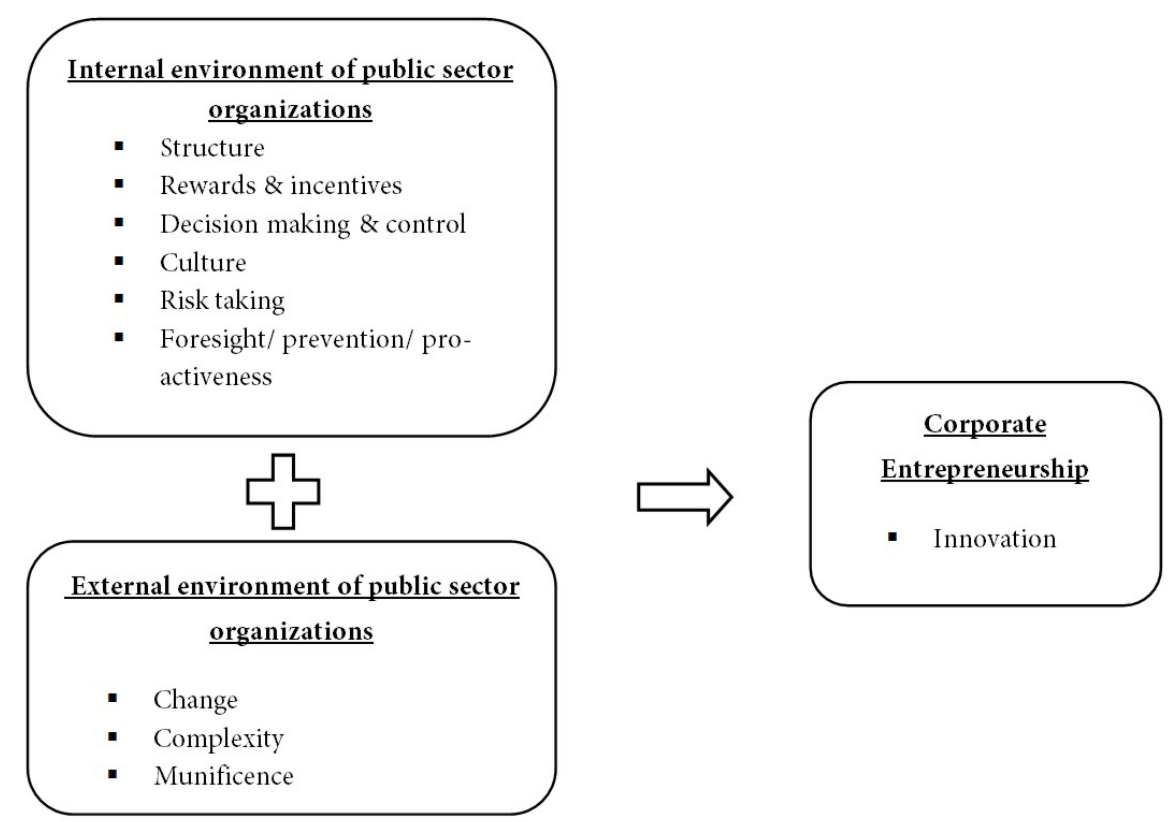

Figure 1. The model of corporate entrepreneurship in the public sector.

Source: Adapted from Kearney et al. (2008, p. 298).

\begin{tabular}{|c|c|}
\hline \multicolumn{2}{|c|}{ Internal environment of public sector organizations } \\
\hline Structure & $\begin{array}{l}\text { Organizations with organic structures and relatively low formalization have higher performance than } \\
\text { those with mechanistic structures and relatively high formalization. Higher performance is positively } \\
\text { related to corporate entrepreneurship. }\end{array}$ \\
\hline Rewards \& incentives & $\begin{array}{l}\text { Higher wages and greater incentives are positively correlated with greater performance and hence } \\
\text { corporate entrepreneurship. }\end{array}$ \\
\hline $\begin{array}{l}\text { Decision making \& } \\
\text { control }\end{array}$ & $\begin{array}{l}\text { Decision-making and control systems of an organization should be structured in such a way so as not } \\
\text { to work against flexibility and creativity. }\end{array}$ \\
\hline Culture & $\begin{array}{l}\text { Culture is the founded stone for the success of an organization. Attitudes that embrace the concepts of } \\
\text { entrepreneurship and innovation are positively related to organizational performance and corporate } \\
\text { entrepreneurship. }\end{array}$ \\
\hline Risk taking & More receptive environments to risk-taking enable corporate entrepreneurship to flourish. \\
\hline Foresight / prevention & $\begin{array}{l}\text { Organizations, which encourage pro-activeness through attitudes and behavior that provide and un- } \\
\text { dertake initiatives for future needs, promote corporate entrepreneurship. }\end{array}$ \\
\hline \multicolumn{2}{|c|}{ External environment of public sector organizations } \\
\hline Change & $\begin{array}{l}\text { Dynamic environments that do not resist change and adapt to new circumstances (including changes } \\
\text { in the political scene), are positively associated with higher performance and a higher rate of corpo- } \\
\text { rate entrepreneurship. }\end{array}$ \\
\hline Complexity & Usually, corporate entrepreneurship thrives in more complex environments. \\
\hline Munificence & $\begin{array}{l}\text { Corporate entrepreneurship prospers in more generous environments characterized by organization- } \\
\text { al development and dynamism. }\end{array}$ \\
\hline
\end{tabular}

Table 1. Factors which influence corporate entrepreneurship in public organizations.

Source: Kearney et al. (2008).

\subsection{TYPES OF INNOVATION IN THE PUBLIC SECTOR}

According to Windrum (2008), there are six types of innovation in the public sector: a) Service innovation which improves the quality of an existing service (such as features and design) or creates a new one. b) Service delivery innovation: it refers to the new or adjusted methods of delivery to citizens or interaction with them to provide certain public services. c) Administrative and organizational innovation: change in the organizational structures within the organization and conduct of administrative processes. d) Conceptual Innovation: it changes the point of view one uses to handle behaviour and attitudes. According to Kim and Hunter (1993), behavior and attitudes predict intentions and vice versa. e) Policy innovation: it changes the way of thinking or behaviour associated with a political belief system (Sabatier \& Weible, 2014). An important factor is the process of learning. f) Systemic Innovation: it refers to the new or improved ways of interaction with other agencies (such as Public-Private Partnerships/ PPP) or knowledge bases. 


\subsection{ORGANIZATIONAL LEARNING}

Senge (1990) considers that the survival and development of an organization reflect on its learning ability. Supportive environments, which encourage creativity and experimentation, are very important in the learning process. The presence of knowledge diffusion from and to other organizations is also essential.

Longo and Cristofoli (2007) are of the opinion that it is possible to plan and manage the process of change in public organizations. However, it is of paramount importance for the entire organization to learn from this process. An ideal for public organizations is to be simultaneously constant learning organizations in order to cultivate proper culture and suitable environment for change and innovation.

Salaman (1995) argues that all learning organizations should adopt the behaviour of the cycle of organizational learning described in Figure 2. Each organization must be aware of what really happens and what kind of knowledge can be gained from the previous experience. Various alternative scenarios should be evaluated and subsequent actions planned in order for the change, innovation and entrepreneurship to be successful and increase the efficiency of an organization.

Generally, the approach of organizational learning takes readiness and alertness of organizational culture of all members within an organization. Surely, it should not neglect the fact that this continuing situation may strain the staff. Last but not least, while the organizational learning may reward risk-taking, this is often not feasible because of the nature, mainly, of public services (such as dealing with vulnerable and disadvantaged social groups). ideas and creative solutions. In the international literature, entrepreneurial behavior is distinguished between individuals and organizations.

Innovation should be treated as a journey and not as a linear process, where the process of learning is viewed as a very important segment through experimentation (either successful or failed). Innovations in the public sector are usually related to provision of public services and changes in links between different parties and political processes. Effective relationships and bonds between innovative and end users/ consumers are the key points for successful innovation in this area. Conversely, innovations in private sector are mostly related to new products, services and/ or production processes (Albury, 2005).

Attitudes and behavior of innovation and entrepreneurship are particularly popular as strategies associated with change. However, these concepts are highly controversial in the public sector. For instance, Goodsell (1993) and Hood (1991) argue that entrepreneurship, as a concept, may be in contrast with traditional values of the public sector, such as accountability, honesty and fairness. Additionally, Moon (1999) believes that the concept of entrepreneurship is not adapted appropriately to its transfer from private to public sector.

In public sector, in general, there is a need for cultural change of the outdated bureaucratic procedures in order to enhance flexibility, innovation and entrepreneurship. Simultaneously, there is a desire to maintain those practices and procedures, as they are necessary to ensure the quality of citizen services.

Schedler and Proeller (2007) perceive culture as something ductile. Indeed, the organizational culture is a key factor for promoting entrepreneurship (Moon, 1999). Empirical research shows that the organizational environment, in turn, affects innovation and entrepreneurship (Parry \& Proctor-Thomson, 2002).

However, despite the pervasiveness of various reforms in the public sector, proper assessment protocols and procedures lag while at the same time the orientation and effectiveness receive many reviews (Zampetakis \& Moustakis, 2007). Bessant (2005) highlights the importance of public sector learning to manage innovation and entrepreneurship, thereby increasing the effectiveness, efficiency and performance of services provided.

In an ideal situation, public organizations should be able to detect change in their environment (internal and external) and assess the repercussions inducing such changes to the organization and services provided. Additionally, public organizations should immediately develop changes, innovation and entrepreneurship in order to be able to respond properly to such continuous changes (Osborne \& Brown, 2005).

Figure 2. Cycle of organizational learning according to Salaman (1995).

Source: Adapted from Osborne \& Brown (2005, p. 41).

\section{SUMMARY}

Public sector changes rapidly both nationally and internationally, thus imposing immediate adaptation of public services in an effective and efficient way (Karyotakis \& Moustakis, 2014). Kuratko (2014) defines entrepreneurship as a dynamic vision of change and creation. According to this perspective, energy and passion are required for creation, implementation of new
In conclusion, the intensely dynamic global sociopolitical environment in coupled with the constant technological changes demands, perhaps more urgently than ever, from public (and not only) organizations to embrace practices and behaviour typical for entrepreneurship. This paper attempts to make this concept clear. Entrepreneurship is crucial for organizations, not only for their development and adaptation to new data, and their development, but also for their survival. 


\section{REFERENCES}

Albury, D. (2005). Fostering Innovation in Public Services. Public Money and Management, 25(1), 51-56. DOI: 10.1111/j.14679302.2005.00450.x.

Alves, H. (2013). Co-creation and innovation in public services. The Service Industries Journal. 33(7-8), 671-682. DOI: 10.1080/02642069.2013.740468.

Audretsch, D. B. (2003). Entrepreneurship: A Survey of the Literature. Enterprise Papers No. 14. Brussels: European Commission.

Baldridge, J. V., \& Burnham, R. A. (1975). Organizational innovation: Individual, organizational, and environmental impacts. Administrative science quarterly, 20(2), 165-176. DOI: $10.2307 / 2391692$.

Benz, M. (2009). Entrepreneurship as a non-profit-seeking activity. International Entrepreneurship and Management Journal, 5(1), 23-44. DOI: 10.1007/s11365-006-0031-y.

Bessant, J. (2005). Enabling continuous and discontinuous innovation: Learning from the private sector. Public Money and Management, 25(1), 35-42. DOI: 10.1111/j.14679302.2005.00448.x.

Covin, J. G., \& Slevin, D. P. (1991). A conceptual model of entrepreneurship as firm behavior. Entrepreneurship theory and practice, 16(1), 7-25. SSRN: http://ssrn.com/abstract $=1504448$.

Currie, G., Humphreys, M., Ucbasaran, D., \& McManus, S. (2008). Entrepreneurial leadership in the English public sector: paradox or possibility? Public Administration. 86(4), 987-1008. DOI: 10.1111/j.1467-9299.2008.00736.x.

Deakins, D., \& Freel, M. (2012). Entrepreneurship and Small Firms (Ed. 6th). Maidenhead: McGraw-Hill.

Goodsell, C. T. (1993). Reinvent government or rediscover it? Public Administration Review. 53(1), 85-87. DOI: $10.2307 / 977283$.

Hisrich, R. D. (2013). International Entrepreneurship: Starting, Developing, and Managing a Global Venture. USA: Sage.

Hood, C. (1991). A public management for all seasons? Public administration, 69(1), 3-19. DOI: 10.1111/j.1467-9299.1991. tb00779.x.

Karyotakis, K. M. \& Moustakis, V. (2014). Reinvention of the Public Sector: Total Quality Management and Change Management. Singidunum Journal of Applied Sciences, 11(2), 30-44. DOI: $10.5937 / S J A S 11-6751$.

Kearney, C., Hisrich, R., \& Roche, F. (2008). A conceptual model of public sector corporate entrepreneurship. International Entrepreneurship and Management Journal, 4(3), 295-313. DOI 10.1007/s11365-007-0048-x.

Kim, M. S., \& Hunter, J. E. (1993). Relationships Among Attitudes, Behavioural Intentions, and Behaviour: A MetaAnalysis of Past Research, Part 2. Communication research, 20(3), 331-364. DOI: 10.1177/009365093020003001.

Kuratko, D. F. (2014). Entrepreneurship: Theory, process, and practice. USA: South-Western Cengage Learning.

Longo, F., \& Cristofoli, D. (2007). Strategic change management in the public sector: an EFMD European case book. Chichester: John Wiley \& Sons.

Moon, M. J. (1999). The pursuit of managerial entrepreneurship: Does organization matter? Public Administration Review, 59(1), 31-43. DOI: 10.2307/977477.

Morris, M. H., \& Jones, F. F. (1999). Entrepreneurship in established organizations: The case of the public sector. Entrepreneurship Theory and Practice, 24(1), 71-91.
Newman, J. (2002). The New Public Management, modernization and institutional change. New public management: current trends and future prospects. In McLaughlin, K., Osborne, S. P., \& Ferlie, E. (Eds.). New Public Management: Current trends and future prospects (77-91). London, New York: Routledge.

Omar, A. R. C., \& Ishak, S. (2013). Organization's Entrepreneurial Behaviors: A Study on Malaysian State Government Links Companies (SGLCS) Practices. Asian Social Science, 9(8), 8795. DOI: 10.5539/ass.v9n8p87.

Osborne, S. P., \& Brown, K. (2005). Managing change and innovation in public service organizations. London, New York: Routledge.

Osborne, S. P., Radnor, Z., Kinder, T., \& Vidal, I. (2014). Sustainable public service organisations: A Public Service-Dominant approach. Society and Economy, 36(3), 313-338. DOI: 10.1556/SocEc.36.2014.3.1.

Ostrom, E. (1965). Public entrepreneurship: a case study in ground water basin management. Los Angeles: University of California. Doctoral Dissertation.

Parry, K., \& Proctor-Thomson, S. (2002). Leadership, culture and performance: The case of the New Zealand public sector. Journal of Change Management, 3(4), 376-399. DOI: 10.1080/714023843.

Pearce II, J. A., Kramer, T. R., \& Robbins, D. K. (1997). Effects of managers' entrepreneurial behavior on subordinates. Journal of Business Venturing, 12(2), 147-160. DOI: 10.1016/ S0883-9026(96)00066-3.

Rubalcaba-Bermejo, L. (2007). The new service economy: challenges and policy implications for Europe. Cheltenham UK and Northampton MA USA: Edward Elgar Publishing.

Sabatier, P. A., \& Weible, C. (Eds.). (2014). Theories of the policy process ( $3^{\text {rd }}$ Ed.). USA: Westview Press.

Salaman, G. (1995). Managing. Buckingham: Open University Press. Schedler, K., \& Proeller, I. (Eds.) (2007). Cultural Aspects of Public Management Reform (29-64), Amsterdam: Elsevier.

Senge, P. (1990). The Fifth Discipline. New York: Doubleday.

Stevenson, H. H., \& Jarillo, J. C. (2007). A Paradigm of Entrepreneurship: Entrepreneurial Management. In Cuervo, A., Ribeiro, D., \& Roig, S. (Eds.). Entrepreneurship: Concepts, Theory and Perspective (155-170). New York: SpringerVerlag Berlin Heidelberg.

Vesper, K. H. (1990). New Venture Strategies. University of Illinois at Urbana-Champaign's Academy for Entrepreneurial Leadership Historical Research Reference in Entrepreneurship. http://ssrn.com/abstract=1496217.

Wagner, R. E. (1966). Pressure groups and political entrepreneurs: A review article. Papers on Non-Market Decision Making, 1(1), 161-170. DOI: 10.1007/BF01718992.

Wilson, J. Q. (2000). Bureaucracy: What government agencies do and why they do it. USA: Basic Books.

Windrum, P. (2008). Innovation and Entrepreneurship in public services. In Windrum, P., \& Koch, P. M. (Eds.), Innovation in Public Sector Services: Entrepreneurship, Creativity and Management (3-20). Cheltenham UK, Northampton MA UA: Edward Elgar Publishing.

Zampetakis, L. A., \& Moustakis, V. (2007). Fostering corporate entrepreneurship through internal marketing: Implications for change in the public sector. European Journal of Innovation Management. 10(4), 413-433. DOI: 10.1108/14601060710828754.

Zampetakis, L. A., \& Moustakis, V. S. (2010). An exploratory research on the factors stimulating corporate entrepreneurship in the Greek public sector. International Journal of Manpower. 31(8), 871-887. DOI: 10.1108/01437721011088557. 